\title{
Improved accuracy of lactose tolerance test in children, using expired $\mathrm{H}_{2}$ measurement
}

\author{
A. C. DOUWES, ${ }^{*}$ J. FERNANDES, AND H. J. DEGENHART
}

From the Department of Paediatrics, Sophia Children's Hospital and Neonatal Unit, Academic Hospital of the Eramus University, Rotterdam

SUMMARY Expired hydrogen and blood glucose were measured during an oral lactose tolerance test in 163 children aged between 9 months and 14 years. Lactose malabsorption, defined as an abnormal increase in expired $\mathrm{H}_{2}$ during a lactose tolerance test, was found in 54 children. Of these, 30 were found to be lactose intolerant as the increased expired $\mathrm{H}_{2}$ was accompanied by clinical symptoms. The other 109 children, in whom there was no rise in expired $\mathrm{H}_{2}$, were assumed to have normal lactose absorption. In children with lactose intolerance the increase in expired $\mathbf{H}_{2}$ tended to occur earlier after lactose ingestion than in children with malabsorption. The mean value of the rise in blood glucose was $2.4 \mathrm{mmol} / 1(43 \mathrm{mg} / 100 \mathrm{ml})$ in the lactose-tolerant children and $1.0 \mathrm{mmol} / 1$ $(18 \mathrm{mg} / 100 \mathrm{ml})$ in the lactose-intolerant ones. Although this difference is significant $(\mathrm{P}<0.001)$, the rise in blood glucose, in predicting the correct diagnosis, was wrong in $13 \%$ of cases in the lactose-tolerant group, and wrong in $37 \%$ in the lactose-intolerant group $(95 \%$ confidence limits $9-19 \%$ and $22-53 \%$ respectively). It is concluded that a rise in blood glucose, whether or not of more than $1.2 \mathrm{mmol} / 1(22 \mathrm{mg} / 100 \mathrm{ml})$ is of little help in differentiating lactose tolerance from intolerance.

Lactose malabsorption is usually diagnosed by the failure of blood glucose to rise normally above the fasting level after an oral lactose tolerance test (LTT). However a subnormal rise in glucose $(\triangle-$ glucose) is an imperfect indicator of lactose malabsorption, as it tells us the portion of lactose which is absorbed, not the portion unabsorbed which is what causes the clinical symptoms. Apart from this, many factors known to influence the blood glucose level render the diagnostic value of $\Delta$-glucose doubtful (Krasilnikoff et al., 1975; Garza and Scrimshaw, 1976; Harrison and Walker-Smith, 1977). It is therefore not surprising that there is no agreement about the value for $\Delta$-glucose diagnostic of lactose malabsorption. It has recently been found that the LTT is interpreted more accurately by measuring expired hydrogen than by $\Delta$-glucose, both in adults (Calloway et al., 1969; Levitt, 1969; Newcomer et al., 1975) and children (Maffei et al., 1977; Fernandes et al., 1978).

Using a procedure for $\mathrm{H}_{2}$ determination, adapted for children and infants (Douwes et al., 1978;

Received 3 March 1978

*Present address: Children's Department, Free University Hospital, Amsterdam, The Netherlands.
Fernandes et al., 1978), we have evaluated the diagnostic value of $\Delta$-glucose in relation to expired $\mathrm{H}_{2}$ and to clinical symptoms after an oral LTT.

\section{Patients and methods}

An LTT was performed on 163 patients ranging in age from 9 months to 14 years. Most had a history of chronic or recurrent diarrhoea and/or unexplained abdominal pain, with or without bloating. Some patients were examined because of inflammatory bowel disease or cystic fibrosis, conditions known to have an increased frequency of lastase deficiency.

Lactose $(2 \mathrm{~g} / \mathrm{kg}$, maximum $50 \mathrm{~g}, 20 \%$ solution) was given orally at 9 a.m. after an overnight fast. Capillary blood was taken by finger prick at -15 , $0,15,30,60,90,120$, and 150 minutes for blood glucose estimation. The mean of the glucose levels at -15 and 0 minutes was taken as the fasting level. A $\Delta$-glucose of $\geqslant 1.2 \mathrm{mmol} / \mathrm{l}$ was considered to be normal.

$\mathrm{H}_{2}$ was measured every 30 min during a period of 180 minutes. In children aged 4 years or older, expired $\mathrm{H}_{2}$ could be measured with a rebreathing system (Fernandes et al., 1978). An excretion $\geqslant 0.1 \mathrm{ml} \mathrm{H}_{2} / \mathrm{min}$ was considered abnormal. In 
younger children and infants expired air was collected from 2 or 3 breaths (Douwes et al., 1978). An increase of $\geqslant 10 \mathrm{ppm} \mathrm{H}_{2}$ above the fasting value was considered abnormal. In 48 children both methods were applied and the results were found concordant positive in 14 , concordant negative in 32 , and discrepant in 2 . The last result was because one valve of the sampler was found to leak.

Lactose malabsorption was diagnosed on one criterion: an abnormal increase of expired $\mathrm{H}_{2}$ during an LTT. Lactose intolerance was diagnosed on two criteria: an abnormal increase of expired $\mathrm{H}_{2}$, and abdominal pain and/or diarrl:oea after the ingestion of lactose.

The patient was considered lactose tolerant if no rise in $\mathrm{H}_{2}$ excretion could be detected.

\section{Results}

In 163 oral LTTs, both expired $\mathrm{H}_{2}$ and blood glucose concentrations were measured. No increase in expired $\mathrm{H}_{2}$ could be detected in 109 children, and these were considered to be lactose tolerant. An abnormal rise of $\mathrm{H}_{2}$, indicating some degree of malabsorption, was found in 54 patients, among whom symptoms were absent in 24 and present in 30. The latter were considered to be lactose intolerant. Final diagnoses of this group are listed in Table 1.

The presence or absence of symptoms was recorded in 45 of the 109 patients who had no rise in $\mathrm{H}_{2}$ production after an oral LTT: 6 of these complained of symptoms. $\Delta$-Glucose of 109 lactosetolerant patients and 54 lactose malabsorbers is shown in Fig. 1A. $\triangle$-Glucose of 109 lactose-tolerant and 30 lactose-intolerant patients is shown in Fig. 1B.

The mean values for $\Delta$-glucose of the patients with lactose malabsorption without clinical symptoms (group 1), lactose intolerance (group 1A), and normal lactose absorption (group 2 ) were $1.4,1 \cdot 0$, and $2.4 \mathrm{mmol} / \mathrm{l}$, respectively. The mean values were significantly different between groups 1A and 2 and between groups 1 and $2(P<0.001)$,

Table 1 Final diagnosis in 30 lactose-intolerant children

\begin{tabular}{lrl}
\hline Diagnosis & $n$ & $\begin{array}{l}\text { Proved lactase } \\
\text { deficiency* }\end{array}$ \\
\hline Lactase deficiency & 16 & 3 \\
$\quad$ Genetic & 9 & 4 \\
$\quad$ Secondary & 2 & 1 \\
Coeliac disease & 1 & \\
Cystic fibrosis & 1 & 1 \\
Short bowel & 1 & \\
Crohn's disease & & \\
\hline
\end{tabular}

*Proved by enzyme assay (the other patients were not biopsied). but not between groups 1 and 1A. However, a wide overlap both above and below the arbitrarily chosen $\Delta$-glucose of $1.2 \mathrm{mmol} / 1$ as the lowest normal value is apparent from Fig. 1. $\triangle$-Glucose failed to indicate the correct condition in half the children in group 1 (lactose malabsorption), $37 \%$ of group $1 \mathrm{~A}$ (lactose intolerance), and $13 \%$ of group 2 (normal lactose absorption) (Table 2). The time interval between lactose administration and an abnormal increase in expired $\mathrm{H}_{2}$ in patients with lactose malabsorption and the subgroup with additional lactose-intolerance is shown in Fig. 2. There is a tendency for a shorter time lag in the intolerant group, but both groups overlapped.

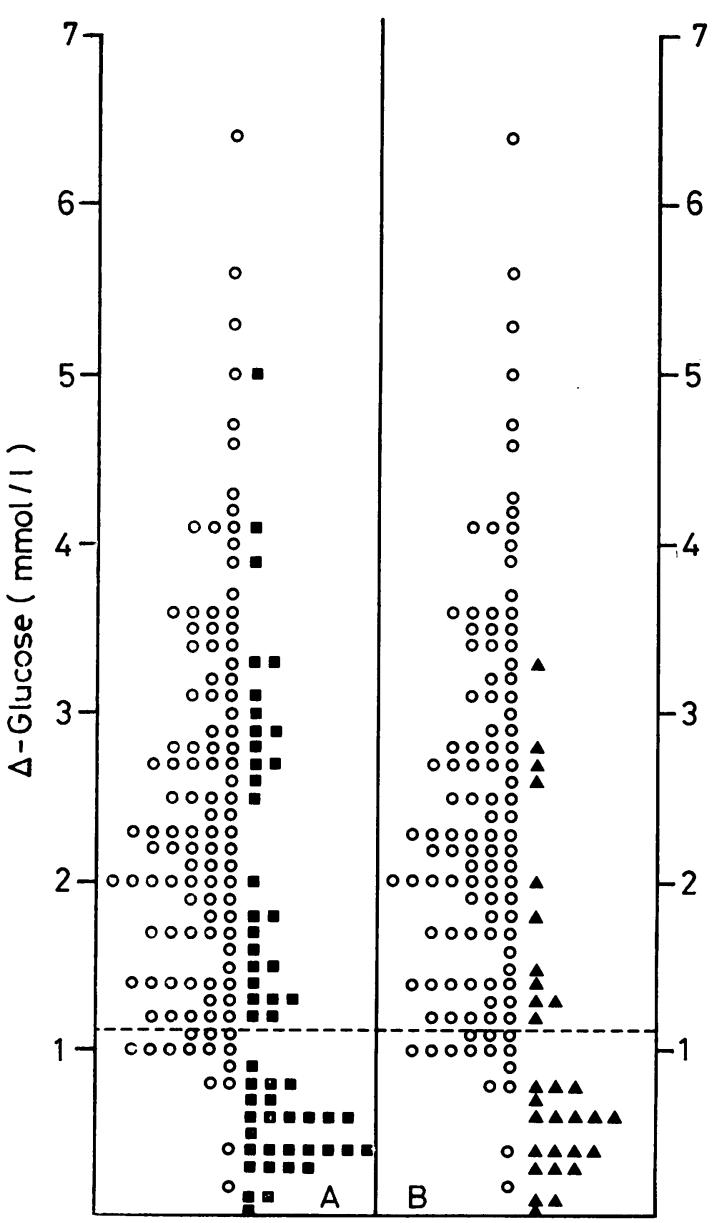

Left side of each column are results in normal chi!dren $=0$; right side of column A: lactose malabsorption $\square$; right side of column B: lactose intolerance $\mathbf{A}$

Fig. $1 \Delta$-Glucose in 163 children during a lactose tolerance test. 
Table $2 \Delta$-Glucose (mmol/l) during a lactose tolerance test

\begin{tabular}{lccc}
\hline$\triangle$-Glucose & Lactose tolerance $(n=109)$ & Lactose malabsorption $\dagger(n=54)$ & Lactose intolerance $\ddagger(n=30)$ \\
\hline Mean & $2 \cdot 43$ & $1 \cdot 43$ & $1 \cdot 02$ \\
Range & $0 \cdot 2-6 \cdot 4$ & $0 \cdot 0-5 \cdot 0$ & $0-3 \cdot 3$ \\
SD & $1 \cdot 17$ & $1 \cdot 20$ & 0.89 \\
False $\%$ & $12 \cdot 8$ & 50 & 36.7 \\
$95 \%$ confidence limits & $8 \cdot 8-18 \cdot 7$ & $38 \cdot 1-61.9$ & $22 \cdot 1-53 \cdot 3$ \\
\hline
\end{tabular}

*Expired $\mathrm{H}_{2}$ not increased; tincreased expired $\mathrm{H}_{2}$; $\ddagger$ increased expired $\mathrm{H}_{2}$ plus abdominal symptoms.

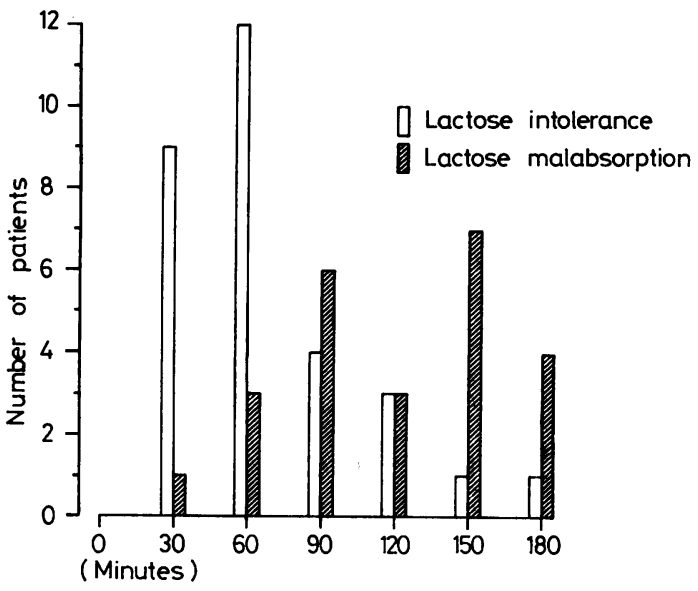

Fig. 2 Time lag between lactose ingestion and abnormal increase of expired $\mathrm{H}_{2}$ in patients with lactose malabsorption and those with lactose intolerance.

\section{Discussion}

It has been emphasised that the peak rise in blood glucose ( $\Delta$-glucose) during an oral LTT can be influenced by factors other than hydrolysis and absorption of the sugar. These factors are of intestinal (peristalsis) and extraintestinal origin (normal or under use of glucose) (Krasilnikoff $e t$ al., 1975; Garza and Scrimshaw, 1976; Harrison and Walker-Smith, 1977). It is therefore not surprising that $\Delta$-glucose after lactose ingestion differentiates poorly between normal lactose absorption and lactose malabsorption (James, 1972; Harrison and Walker-Smith, 1977), lactose intolerance (Garza and Scrimshaw, 1976; Harrison and Walker-Smith, 1977), and lactase deficiency (James, 1972; Krasilnikoff et al., 1975; Newcomer et al., 1975).

Excess of reducing substances in the stool, with high lactic acid content and low $\mathrm{pH}$, if present, are of great help in this differentiation (James, 1972; Harrison and Walker-Smith, 1977), but only a few lactose-intolerant patients show these abnormalities. In the present study 2 of 11 stools examined showed them.

The fact that lactose malabsorption can be detected by increased expired $\mathrm{H}_{2}$, originating from bacterial fermentation of lactose residue in the colon, is an important contribution to the diagnosis. Recent experience shows that the method is accurate and sensitive (Levitt, 1969; Newcomer et al., 1975), and can be adapted easily for children and infants (Maffei et al., 1977; Douwes et al., 1978; Fernandes et al., 1978). Taking normal or increased $\mathrm{H}_{2}$ excretion as a reflection of normal or poor absorption of lactose, this parameter has been used to evaluate $\Delta$-glucose during an LTT in children (Maffei et al., 1977). Maffei et al. measured expired $\mathrm{H}_{2}$ in 23 children with chronic diarrhoea and in 4 controls during LTT. They found no correlation between the $\mathrm{H}_{2}$ production and blood glucose rise, but blood glucose was measured in only 7 of the $\mathrm{H}_{2}$-producing patients and in 2 controls. We agree with their conclusions, but find the number of observations too small.

In the present study, of 163 children 54 showed increased $\mathrm{H}_{2}$ during an LTT. Of these, 27 showed a normal $\Delta$-glucose $(\geqslant 1.2 \mathrm{mmol} / \mathrm{l})$ (Fig. 1). Thus half of the lactose malabsorbers had a false normal $\Delta$-glucose. 30 of the 54 malabsorbers were diagnosed as being intolerant because they had clinical symptoms; of these 11 showed a normal $\Delta$-glucose. This amounts to $37 \%$ with a falsely normal $\Delta$ glucose. 109 patients showed no increased $\mathrm{H}_{2}$ excretion and were therefore assumed to be lactose tolerant. Of these 14 had a $\Delta$-glucose $<1.2 \mathrm{mmol} / \mathrm{l}$, which amounts to an error of $13 \%$. Extrapolating these results to larger populations, the incidence of a false normal $\Delta$-glucose would have been $38-62 \%$ for lactose malabsorption, and $22-53 \%$ for lactose intolerance, and the incidence of a false abnormal $\triangle$-glucose $9-19 \%$ for lactose tolerance (Table 2). Thus, $\Delta$-glucose during the LTT, appears to be an unreliable indicator of lactose malabsorption and lactose intolerance, and should be replaced by more reliable methods-such as the $\mathrm{H}_{2}$ test.

Although we did not aim to use the $\mathrm{H}_{2}$ test for differentiating lactose malabsorption from lactose intolerance, we confirmed the observation of Maffei et al. (1977) that the increase in $\mathrm{H}_{2}$ excretion tends to be early in lactose-intolerant patients (Fig. 2). However, the time lag between lactose administration and an increase in $\mathbf{H}_{2}$ excretion overlaps in both conditions. Furthermore, we noticed that some 
of the patients with an early rise of expired $\mathrm{H}_{2}$ and biopsy-proved lactase deficiency, did not develop symptoms during or shortly after the test but did do so on a repeat test. These facts suggest that there is a gradual transition from lactose malabsorption to lactose intolerance.

We thank Els Slotema and Ludy van Winsen for performing the tests; Drs J. G. M. Huymans, A. Klippel, N. G. C. Laheij, and W. Rietveld for their help; Dr R. G. Pearse for help with the manuscript; and the Children's Department of the Free University, Amsterdam for financial support.

\section{References}

Calloway, D. H., Murphy, E. L., and Bauer, D. (1969). Determination of lactose intolerance by breath analysis. American Journal of Digestive Diseases, New Series, 14, 811-815.

Douwes, A. C., Fernandes, J., and Rietveld, W. (1978). Hydrogen breath test in infants and children: sampling and storing expired air. Clinica chimica acta, 82, 293-296.

Fernandes, J., Vos, C. E., Douwes, A. C., Slotema, E., and Degenhart, H. J. (1978). Respiratory hydrogen excretion as a parameter for lactose malabsorption in children. American Journal of Clinical Nutrition, 31, 597-602.
Garza, C., and Scrimshaw, N. S. (1976). Relationship of lactose intolerance to milk intolerance in young children. American Journal of Clinical Nutrition, 29, 192-196.

Harrison, M., and Walker-Smith, J. A. (1977). Reinvestigation of lactose intolerant children: lack of correlation between continuing lactose intolerance and small intestinal morphology, disaccharidase activity, and lactose tolerance tests. Gut, 18, 48-52.

James, W. P. T. (1972). Comparison of three methods used in the assessment of carbohydrate absorption in malnourished children. Archives of Disease in Childhood, 47, 531-536.

Krasilnikoff, P. A., Gudmand-Høyer, E., and Moltke, H. H. (1975). Diagnostic value of disaccharide tolerance tests in children. Acta paediatrica Scandinavica, 64, 693-698.

Levitt, M. D. (1969). Production and excretion of hydrogen gas in man. New England Journal of Medicine, 281, 122-127.

Maffei, H. V. L., Metz, G., Bampoe, V., Shiner, M., and Brook, C. G. D. (1977). Lactose intolerance, detected by the hydrogen breath test, in infants and children with chronic diarrhoea. Archives of Disease in Childhood, 52, 766-771.

Newcomer, A. D., McGill, D. B., Thomas, P. J., and Hofmann, A. F. (1975). Prospective comparison of indirect methods for detecting lactase deficiency. New England Journal of Medicine, 293, 1232-1236.

Correspondence to Dr A. C. Douwes, Children's Department, Free University Hospital, Amsterdam, The Netherlands. 